\title{
PEMBELAJARAN ENGLISH VOCABULARY BAGI MAHASISWA SEMESTER II PROGRAM STUDI TEKNIK LINGKUNGAN STTL MATARAM TAHUN AKADEMIK 2020-2021
}

\author{
BIDARITA WIDIATI \\ Sekolah Tinggi Teknik Lingkungan Mataram \\ Email : bidaritawidiati111@gmail.com
}

\begin{abstract}
ABSTRAK
Penelitian ini bertujuan untuk menigkatkan pemahaman dalam pembelajaran kosakata (vocabulary) pada mahasiswa program studi Teknik Lingkungan STTL Mataram tahun akademik 2020-2021. Metode yang digunakan dalam penelitian ini adalah metode Research and Development yang dalam hal ini dilakukan pada 20 orang mahasiswa semester II program studi Teknik Lingkungan. dalam pembelajaran kosakata (vocabulary) yang tertera pada sebuah teks bacaan yang berjudul Industrial Wastewater Treatment and Its Problems. Hasil penelitian ini adalah pemerolehan nilai A (excellent) yang pada awal pembelajaran hanya 3 orang meningkat menjadi 5 orang. Terjadi peningkatan dari $15 \%$ menjadi $25 \%$. Nilai B (good) dari awal 7 orang menjadi 10 orang. Hal ini berarti bahwa peningkatannya dari 35\% menjadi 50\%. Sehingga, nilai C (poor) mengalami penurunan dari 10 orang menjadi 5 orang (50\% menjadi $25 \%$ ). Dengan bertambahnnya mahasiswa yang memperoleh nilai A sebanyak $10 \%$, nilai B sebanyak $15 \%$, dan berkurangnya nilai C sebanyak 25\%, maka dapat disimpulkan bahwa terjadi peningkatan kemampuan mahasiswa dalam pembelajaran kosakata (vocabulary) bahasa Inggris.
\end{abstract}

Kata Kunci : Metode Pembelajaran, Pembelajaran English Vocabulary

\section{PENDAHULUAN}

Bahasa adalah media komunikasi untuk menyampaikan sebuah informasi. Melalui bahasa, pendengar akan menjadi semakin mudah dalam memahami informasi atau ide yang disampaikan oleh penuturnya. Dalam kehidupan sosial, bahasa dapat bermacam-macam jenisnya karena bahasa dituturkan oleh penutur yang berbeda latar belakang, kebudayaan dan kemampuan dalam menuturkannya. Ada beragam macam bahasa yang sering ditemui yaitu: bahasa daerah, bahasa nasional, bahkan bahasa asing.

Bahasa daerah terbentuk dari kebudayaan, kebiasaan, dan adat di daerah tersebut dan sering juga disebut sebagai bahasa ibu (mother tongue). Itulah sebabnya bahasa pada tiap daerah bisa berbeda-beda. Sedangkan bahasa nasional adalah bahasa pemersatu untuk penutur bahasa daerah yang berbeda-beda. Bahasa nasional yang dipakai di Indonesia adalah bahasa Indonesia. Bahasa nasional adalah bahasa yang menjadi bahasa standar atau lingua franca di negara yang mempunyai banyak bahasa karena perkembangan sejarah, kesepakatan bangsa, atau ketetapan perundang-undangan (KBBI.com, 2020). Sedangkan bahasa asing merupakan bahasa yang diperoleh melalui pembelajaran secara formal melalui lembaga-lembaga pendidikan atau institusi yang didirikan khusus untuk mempelajari bahasa asing (Bahasa Inggris).

Bahasa Inggris disebut juga sebagai bahasa Internasional yang tertera di dalam kurikulum pendidikan di Indonesia mulai dari pendidikan menengah sampai jenjang pendidikan tinggi. Bahasa Inggris dikenalkan kepada siswa untuk dipelajari sebagai bahasa asing (foreign language) dengan tingkat pemahaman yang berbeda-beda pada setiap siswa. Ada siswa yang tergolong mudah memahami, ada yang tergolong sedang, dan ada juga yang tergolong lemah dalam menerima pembelajaran Bahasa Inggris.

Dengan melihat kemampuan berbahasa Inggris yang berbeda-beda inilah penulis terdorong melakukan penelitian pada mahasiswa di Sekolah Tinggi Teknik Lingkungan (STTL) Mataram sebagai tempat peneliti mengajar dan mengingat kemampuan berbahasa Inggris mahasiswa STTL Mataram program studi Teknik Lingkungan pada semseter II yang tergolong masih rendah. Dalam pelaksanaan penelitian ini, penulis memberikan perlakuan khusus kepada 
para mahasiswa dalam rangka meningkatkan kemampuan mereka dalam pembelajaran kosakata Bahasa Inggris.

Dalam pembelajaran Bahasa Inggris, ada banyak sekali aspek yang perlu diperhatikan, seperti penguasaan grammar, vocabulary (kosakata), pengucapan, dan lain sebagainya (Burns, dkk. 2015). Sebagai salah satu bagian pembelajaran Bahasa Inggris yang utama, penguasaan kosakata menjadi dasar untuk dapat menguasai dan berkomunikasi dalam Bahasa Inggris (Alderson \& Bachman. 2000). Penelitian tentang pembelajaran kosa kata (vocabulary) ini sudah banyak sekali dilakukan oleh para peneliti. Abu, dkk. (1986) dalam Mardika (2008) menyatakan bahwa kosakata berasal dari bahasa Sansekerta koca dan katha. Kedua kata tersebut diserap ke dalam bahasa Indonesia sebagai kata majemuk. Perbendaharaan kosakata tiap orang berbeda-beda. Hal ini sangat menentukan komunikasi seseorang dalam berinteraksi sosial.

Penguasaan kosa kata sangat penting untuk kelancaran dalam berkomunikasi. Seperti yang ditegaskan oleh Mardika (2008) bahwa semakin kaya kosa kata yang dimiliki seseorang, maka semakin besar pula kemungkinan terampil berbahasa. Jika seseorang sangat terampil dan lancar berbicara, maka dapat dipastikan bahwa kosakata yang dimiliki oleh orang tersebut sangat luas.

Menurut Lado (1979) dalam Mardika (2008), ada beberapa langkah yang dapat diterapkan dalam pembelajaran kosakata yaitu: (1) mendengarkan kata, (2) mengucapkan kata, (3) memahami makna, (4) membuat ilustrasi dalam bentuk kalimat, (5) melakukan latihan dan pengekspresian makna, (6) mengucapkan kata tersebut dengan suara keras, dan (7) menulis kata-kata tersebut. Langkah-langkah dalam pembelajaran kosa kata di atas, diterapkan juga dalam penelitian yang dilakukan peneliti pada mahasiswa program studi Teknik Lingkungan STTL Mataram.

Penelitian yang dilakukan ini menggunakan metode Research and Development yang dimaksudkan untuk meningkatkan kemampuan mahasiswa. Menurut Prasetyo (2020), sesuai namanya, Research and Development diartikan sebagai kegiatan penelitian yang dimulai dengan research dan diteruskan dengan development. Kegiatan research dilakukan untuk mendapatkan informasi tentang kebutuhan pengguna (needs assessment) sedangkan kegiatan development dilakukan untuk menghasilkan perangkat pembelajaran.

Latief (2012) dalam Rahayu dan Riska (2017) menyatakan bahwa educational research and development is a research design aimed at developing educational products, like curriculum, syllabus, textbooks, instructional media, modules, assessment instrument, etc. yang berarti bahwa penelitian dan pengembangan akan menghasilkan produk pendidikan berupa kurikulum, silabus, buku, media pembelajaran, modul, instrumen penilaian, dan lain-lain. Ditambahkan juga oleh Haryati (2012) produk yang dihasilkan bisa berupa model, pola, prosedur, sistem yang dalam bidang pendidikan hasil tersebut diharapkan dapat meningkatkan produktivitas pendidkan, yaitu lulusan yang jumlahnya banyak, berkualitas, dan relevan dengan kebutuhan.

\section{METODE PENELITIAN}

Metode yang digunakan dalam penelitian ini adalah metode Research and Development atau penelitian dan pengembangan. Dalam hal ini, peneliti melakukan research (penelitian) terlebih dahulu lalu menghasilkan pengembangan (development) dalam bentuk media pembelajaran. Penelitian ini dilakukan pada 20 orang mahasiswa semester II program studi Teknik Lingkungan STTL Mataram dalam pembelajaran kosakata (vocabulary) yang tertera pada sebuah teks bacaan berbahasa Inggris yang berjudul Industrial Wastewater Treatment and Its problems. Di dalam bacaan tersebut, berisi kosakata yang tergolong asing dan jarang didengar oleh mereka tetapi sangat penting untuk dikuasai oleh mahasiswa teknik lingkungan karena sangat erat penggunaannya dengan kehidupan sehari-hari dan lingkungan kerja.

Dalam penelitian ini, mahasiswa diberikan 15 kosa kata baru yang ada di dalam teks tersebut, kemudian diminta untuk mengucapkan kosa kata tersebut beserta artinya dalam bahasa 
Indonesia. Hal ini dilakukan untuk mengetahui tingkat kemampuan awal mahasiswa dalam mengucapkan (pronunciation) dan memberi arti kosakata yang diberikan dengan memilih katakata dalam bahasa Indonesia. Setelah itu, mahasiswa diminta untuk mengisi rumpang dalam kalimat-kalimat yang diberikan untuk membantu mahasiswa menggunakannya dalam kalimat yang tepat. Setelah didapatkan data awal kemampuan mahasiswa, maka penelitian dilanjutkan dengan memberikan perlakuan pelayanan pada mahasiswa.

Perlakuan pelayanan yang dimaksud berupa model pengucapan kosakata yang benar sekaligus menyediakan arti kosakata tersebut dan memberikan arahan ketika mahasiswa menjodohkan kosakata dengan artinya dalam bahasa Indonesia. Setelah itu, mahasiswa diberikan arahan lagi agar mampu menggunakan kosa kata tersebut dalam rumpang yang diberikan dalam kalimat.

\section{HASIL DAN PEMBAHASAN}

Dalam pelaksanaan penelitian ini, dibuatkan pengelompokan kemampuan mahasiswa menjadi 3 kategori, yaitu: kategori A (excellent) nilai 85-100, kategori B (good) nilai 61-84, dan kategori C (poor) nilai 1-60. Pengelompokan di atas merupakan titik awal dimulainya pembelajaran oleh peneliti sebagai titik tumpu dari penghitungan perkembangan hasil belajar mahasiswa selanjutnya.

Dari penelitian yang sudah dilakukan pada 20 orang mahasiswa semester II program studi Teknik Lingkungan STTL Mataram, diperoleh data awal bahwa terdapat 3 orang mahasiswa berada pada level A (excellent), 7 orang mahasiswa pada level B (good), dan 10 orang mahasiswa pada level $\mathrm{C}$ (poor). Jika dibuat dala bentuk pro sentase, maka nilai A sebanyak $15 \%$, nilai B sebanyak 35\%, dan nilai C sebanyak 50\%. Berikut hasil yang diperoleh mahasiswa disajikan dalam tabel di bawah ini.

Tabel 1. Hasil Nilai Awal Mahasiswa Sebelum Tindakan

\begin{tabular}{|l|l|l|l|}
\hline No & Nama & Nilai & Keterangan \\
\hline 1. & Septika Ariyanti & 70 & B \\
\hline 2. & Mifta Hayatun & 85 & A \\
\hline 3. & Ihwanul Hakim & 40 & C \\
\hline 4. & Jiliani & 60 & C \\
\hline 5. & Yusi Ramadani & 50 & $\mathrm{C}$ \\
\hline 6. & Misnawati & 40 & $\mathrm{C}$ \\
\hline 7. & Siprianus Sapulete Bili & 50 & $\mathrm{C}$ \\
\hline 8. & Ishak Juseran & 70 & $\mathrm{~B}$ \\
\hline 9. & Yeniati & 70 & $\mathrm{~B}$ \\
\hline 10. & Yulius & 60 & $\mathrm{C}$ \\
\hline 11. & Yohanis Umbu & 70 & $\mathrm{~B}$ \\
\hline 12. & Yakub Dendo & 50 & $\mathrm{C}$ \\
\hline 13. & Servianus & 65 & $\mathrm{~B}$ \\
\hline 14 & Misman Wari & 70 & $\mathrm{~B}$ \\
\hline 15 & Melki bura & 60 & $\mathrm{C}$ \\
\hline 16 & Agan Afdholi & 55 & $\mathrm{C}$ \\
\hline 17 & Sariyanti & 50 & $\mathrm{C}$ \\
\hline 18 & Yunince & 50 & $\mathrm{C}$ \\
\hline 19 & M. Agam Kurniawan & 90 & $\mathrm{~A}$ \\
\hline 20. & Aqmar Karimul & 85 & $\mathrm{~A}$ \\
\hline
\end{tabular}

Dengan melihat data perolehan mahasiswa pada tabel I di atas, dengan perolehan nilai A (excellent) sebanyak 15\%, nilai B (good) sebanyak 35\% dan nilai C (poor) sebanyak 50\%, dapat dikatakan bahwa tingkat kemampuan mahasiswa dalam pembelajaran kosa kata bahasa Inggris 
(vocabulary) masih rendah. Setengah dari jumlah keseluruhan mahasiswa pada kelas tersebut mendapatkan nilai rendah.

Dalam upaya meningkatkan kemampuan mahasiswa pada pembelajaran tersebut, selanjutnya diberikan perlakuan kepada mahasiswa. Setelah diberikan perlakuan, maka didapatkan data perolehan mahasiswa dengan nilai A (excellent) sebanyak 5 orang, nilai $B$ (good) sebanyak 10 orang, dan nilai C (poor) sebanyak 5 orang. Berikut data perolehan mahasiswa disajikan pada tabel 2.

\section{Tabel 2. Hasil Nilai Mahasiswa Setelah Tindakan}

\begin{tabular}{|l|l|l|l|}
\hline No & Nama & Nilai & Keterangan \\
\hline 1. & Septika Ariyanti & 70 & A \\
\hline 2. & Mifta Hayatun & 85 & A \\
\hline 3. & Ihwanul Hakim & 40 & B \\
\hline 4. & Jiliani & 60 & B \\
\hline 5. & Yusi Ramadani & 50 & C \\
\hline 6. & Misnawati & 40 & B \\
\hline 7. & Siprianus Sapulete Bili & 50 & C \\
\hline 8. & Ishak Juseran & 70 & B \\
\hline 9. & Yeniati & 70 & A \\
\hline 10. & Yulius & 60 & C \\
\hline 11. & Yohanis Umbu & 70 & B \\
\hline 12. & Yakub Dendo & 50 & C \\
\hline 13. & Servianus & 65 & B \\
\hline 14 & Misman Wari & 70 & B \\
\hline 15 & Melki bura & 60 & C \\
\hline 16 & Agan Afdholi & 55 & B \\
\hline 17 & Sariyanti & 50 & B \\
\hline 18 & Yunince & 50 & B \\
\hline 19 & M. Agam Kurniawan & 90 & A \\
\hline 20. & Aqmar Karimul & 85 & A \\
\hline
\end{tabular}

Melihat hasil pemerolehan mahasiswa pada tabel 2 di atas, terdapat perubahan dengan adanya peningkatan pemerolehan. Hal ini berarti bahwa setelah diberikan perlakuan pembelajaran kepada mahasiswa ternyata ada peningkatan nilai. Peningkatan nilai yang dimaksudkan berarti mahasiswa mampu menyebutkan kosakata yang diberikan dengan cara pengucapan yang benar dan juga mampu menyebutkan arti kosakata tersebut dalam Bahasa Indonesia serta mampu menggunakan kosakata yang diberikan dalam kalimat rumpang.

\section{KESIMPULAN}

Berdasarkan hasil penelitian yang telah dilakukan pada mahasiswa semester II program studi Teknik Lingkungan STTL Mataram pada pembelajaran tentang kosakata (vocabularies) yang terdapat dalam text Industrial Wastewater Treatment and Its problems, disimpulkan bahwa terdapat peningkatan kemampuan mahasiswa dalam pembelajaran kosakata bahasa Inggris. Hal ini ditunjukkan dengan adanya perubahan pemerolehan nilai mahasiswa.

Pemerolehan nilai A (excellent) yang pada awal pembelajaran hanya 3 orang meningkat menjadi 5 orang. Terjadi peningkatan dari $15 \%$ menjadi $25 \%$. Nilai B (good) dari awal 7 orang menjadi 10 orang. Hal ini berarti bahwa peningkatannya dari $35 \%$ menjadi 50\%. Sehingga, nilai $\mathrm{C}$ (poor) mengalami penurunan dari 10 orang menjadi 5 orang (50\% menjadi $25 \%$ ). Dengan bertambahnnya mahasiswa yang memperoleh nilai A sebanyak $10 \%$, bertambahnya pemerolehan nilai B sebanyak 15\%, dan berkurangnya pemerolehan nilai $\mathrm{C}$ sebanyak $25 \%$, maka dapat disimpulkan bahwa terjadi peningkatan kemampuan mahasiswa dalam 
pembelajaran kosakata (vocabulary) bahasa Inggris pada text tentang Industrial Wastewater Treatment and Its problems.

Disarankan kepada para peneliti dan pengajar lain untuk mecoba menerapkan pembelajaran kosakata bahasa Inggris melalui text, bahkan mengembangkannya dengan penyempurnaan yang diperlukan.

\section{DAFTAR PUSTAKA}

Alderson, J.C. \& Bahman, L.F. (2000). Assessing Vocabulary. Cambridge Language Assessment. Cambridge: Cambridge University Press.

Burns, A. F. dkk. 2015. Theorizing and Studying the Language-Teaching Mind:Mapping Research on Language Teacher Cognition. The Modern Language Journal, 99(3), 585601.

Ervina. Industrial Wastewater Treatment and Its Problems. http://www.coursehero.com/file/89295523/chemicalpdf/

Haryati, Sri. (2012). Research and Development (R\&D) Sebagai Salah Satu Model Penelitian Dalam Bidang Pendidikan. Majalah Ilmiah Dinamika 37 (1), 15.

Kamus Besar Bahasa Indonesia Online ed. 3. www.kamusbesar.com diunduh pada 15 April 2021

Latief, M.A. (2012). Research Methods on Language Learning an Introduction. Malang: UM Press.

Mardika, I Nyoman (2008). Pengembangan Multimedia DalamPembelajaran Kosa kata Bahasa Inggris di SD. Repositori Institusi Kemendikbud.

Prasetyo, Iis. (2012). Teknik Analisis Data dalam Research and Development. Yogyakarta. Academia.edu.

Rahayu, W.A \& Riska, S.Y. (2017). Developing English Vocabulary Learning Game. Malang: STMIK Asia Malang. 